\title{
Anti-HCV reactive volunteer blood donors distribution character and genotypes switch in Xi'an, China
}

Qiao-hong Yue ${ }^{1}$, Xian-qing Zhang ${ }^{2}$, Yu Shang ${ }^{3}$, Yao-zhen Chen², Wen-li Sun ${ }^{2}$, Min-quan Su', Shi-jie Mu²*, Xiao-ke $\mathrm{Hao}^{1^{*}}$, Xing-bin $\mathrm{Hu}^{2^{*}}$

\begin{abstract}
HCV is prevailed in the world as well as in China. Blood transfusion is one of the most common transmission pathways of this pathogen. Although data of HCV infection character were reported during the past years, anti-HCV reactive profile of China donors was not fully clear yet. Furthermore, infection progress was found related to the HCV genotype. Different genotype led to different efficacy when interferon was introduced into HCV therapy. Here we provided character data of HCV infection in China blood donors from the year of 2000 to 2009. The infection rate in local donors was lower than general population and descended from $0.80 \%$ to $0.40 \%$ or so in recent years. About $83 \%$ HCV strains were categorized into genotypes $1 \mathrm{~b}$ and $2 \mathrm{a}$. But $1 \mathrm{~b}$ subtype cases climbed and 2a subtype cases decreased. The current study threw more light on HCV infection of blood donors in China, at least in the Northern region.
\end{abstract}

\section{Background}

Hepatitis $\mathrm{C}$ virus $(\mathrm{HCV})$ infection rate is about $3 \%$ and more than 170 million people are currently infected by $\mathrm{HCV}$ in the world [1]. More than 3.5 million new sufferers annually occurred [2]. The situation is more serious in China because more than 50 million HCV cases located in this country [3]. This infection, mainly transmitted by blood transfusion in China, could progress to cirrhosis liver and hepatocarcinoma [4].

$\mathrm{HCV}$ is an enveloped virus with a single strand positive and non- fragment RNA. The genome of HCV is about 9400 nucleotides, which encodes approximately 3 000 amino acids [5]. The high heterogenic nucleotides of HCV were confirmed and at least six different genotypes have generally been divided [6,7]. Furthermore, $\mathrm{HCV}$ quasispecies were clarified also according to more detailed $\mathrm{HCV}$ genome variation [8-10].

\footnotetext{
* Correspondence: musj@fmmu.edu.cn; haoxk@fmmu.edu.cn; hxbyqh@fmmu. edu.cn

'Department of Clinic Molecular Research Center\& Clinic Diagnostic Laboratory, Xijing Hospital, Fourth Military Medical University, 17th Changlexi Road, Xi'an 710032, China

2Department of Blood Transfusion, Xijing Hospital, the Fourth Military

Medical University,17th Changlexi Road, Xi'an 710032, China

Full list of author information is available at the end of the article
}

The distribution of HCV genotypes and subtypes depends on geographical location and race deference $[2,7,8,11]$. Type $1 \mathrm{a}$, the first identified sequence, was popular in the United States, while Asia cases were observed also. About 10-30\% HCV infection belonged to type $2 \mathrm{a}$ and $2 \mathrm{~b}$ virus in the world. Type $2 \mathrm{a}$ and $2 \mathrm{~b}$ pathogens prevailed in the North America, Europe, China and Japan. Type 2c strains occurred only in the North region of Italy. Type 3 viruses were more observed in India, Southeast Asia and Indonesia. But type 3a strain prevailed in drug users in the North Europe and United States and mixed with type 1a virus infection. Type 4 virus was mainly reported in the Mediterranean Sea country. More than 39.2\% cases belonged to type 5 family in the South Africa. Type 6 virus infections concentrated in the Southwest of China, including Hong Kong and Taiwan region.

It is significant to discern HCV genotype because infection progress was found related to the nuclei acid sequence variation $[12,13]$. Different genotype led to different efficacy when interferon was introduced into $\mathrm{HCV}$ therapy [14]. Actually, HCV genotypes were regarded as an independent prediction factor in interferon 
administration [15]. Thus HCV genotyping research is necessary in clinic, including transfusion medicine.

Although HCV genotyping was once performed in China, the infection character and genotype distribution is not fully clear yet in blood donors [16-18]. Since gene sequence variation may lea possible failure in donor's screen test, it is imperative to obtain epidemiological data to decrease the blood transmission risk.

The aim of this study was to analyze the HCV epidemiology in local donor population in the past 10 years. The distribution and formulation of HCV infection was also clarified here. HCV genotypes of local blood donors were probed in the current study.

\section{Results}

Infection rate in the last 10 years decreased

To determinate the HCV infection rate in local blood donors, ELISA was performed according to the standard donor peripheral blood test procedure. From the January of 2000 to the December of 2009, about $0.45 \%$ (1151/ 273203) blood donors were found with anti-HCV positive reaction. As shown in Fig. 1, the infection rate is higher in the early of the study period. In the year of 2001, $0.81 \%$ donors were anti-HCV reactive. From the year of 2004, anti-HCV reactive rate in donors decreased to $0.42 \%$ and kept stable in the followed years. In the year of 2010 , HCV infection rate is $0.54 \%$ hitherto $\left(117 / 21578\right.$, up to $31^{\text {st }}$ May, 2010). Those data implied that anti-HCV reactive donors decreased in the latest 5 years in local region.

\section{Most of the anti-HCV reactive donors were low-grade infection}

The relative value of sample absorbance and cutoff ( $\mathrm{S} /$ $\mathrm{CO}$ ) can somewhat reflect the degree of HCV infection. Thus we divided the 1151 anti-HCV reactive donors into different groups (Fig. 2A, black). More than 50\% anti-HCV reactive donors' $\mathrm{S} / \mathrm{CO}$ values were fewer than 2.0 , while about $45 \%$ anti-HCV reactive donors' $\mathrm{S} / \mathrm{CO}$ values were between 2.1 and 4.0. In ALT level measurement, more than $80 \%$ anti-HCV reactive donors' value was between $40 \mathrm{IU} / \mathrm{L}$ and $120 \mathrm{IU} / \mathrm{L}$ (Fig. 2B, black), while only a few donors' value was lower than $40 \mathrm{IU} / \mathrm{L}$ or higher than $120 \mathrm{IU} / \mathrm{L}$. The 200 recruited donors for genotyping displayed similar distribution character (Fig. $2 \mathrm{~A}$ and $2 \mathrm{~B}$, blank), which meant that the chosen sample pool, at least in part, could represent the total $\mathrm{HCV}$ infected donors in the current study. When HCV viral load detection was performed in the 200 recruited donors, about $61 \%$ samples' viral load were between $1 \times$ $10^{2}$ and $1 \times 10^{3}$ copies $/ \mathrm{ml}$, while $16.3 \%$ samples' viral load fell into $1 \times 10^{4}$ copies $/ \mathrm{ml}$ (Fig. 2C). Altogether, these results suggested that most of the local anti-HCV reactive donors, without syndromes, had a low-grade infection when their blood collected.

\section{Genotypes distribution and changes in local region}

To explore the HCV genotypes of local donors in the past 10 years, we chose 20 samples each year to perform genotyping. As shown in Table 1, 135 (67.5\%) donors were $1 \mathrm{~b}$ infection and 31 donors (15.5\%) were $2 \mathrm{a}$ infection. The donor's age or sex was not associated with HCV infection. To be noted, 2 donors were mixed infection ( $1 \mathrm{~b}$ and $2 \mathrm{a}$ ) and 3 donors' infection genotype was not clarified. Furthermore, we compared $1 \mathrm{~b}$ and $2 \mathrm{a}$ subtypes infection between donors and clinic confirmed patients. Results showed that $1 \mathrm{~b}$ and $2 \mathrm{a}$ subtypes infection was no difference in these two groups (Fig. 3A). These data indicated that most of the local anti-HCV reactive donors infected with $1 \mathrm{~b}$ and $2 \mathrm{a}$ subtypes virus.

Since $1 \mathrm{~b}$ and $2 \mathrm{a} \mathrm{HCV}$ virus were the prevailed strains in local infected donors, we are wondering whether the

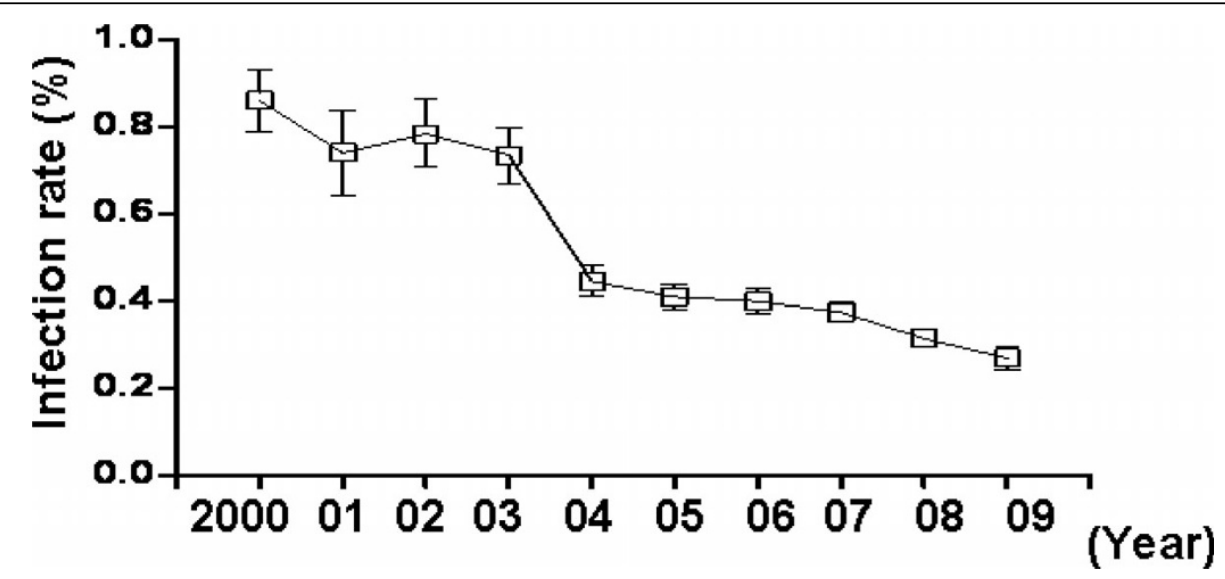

Figure $1 \mathrm{HCV}$ infection rate in blood donors from the year of $\mathbf{2 0 0 0}$ to 2009. Donors' peripheral blood serum were isolated and employed to ELISA to test reactive anti-HCV antibody. Bars represent the $95 \%$ confidence interval. 


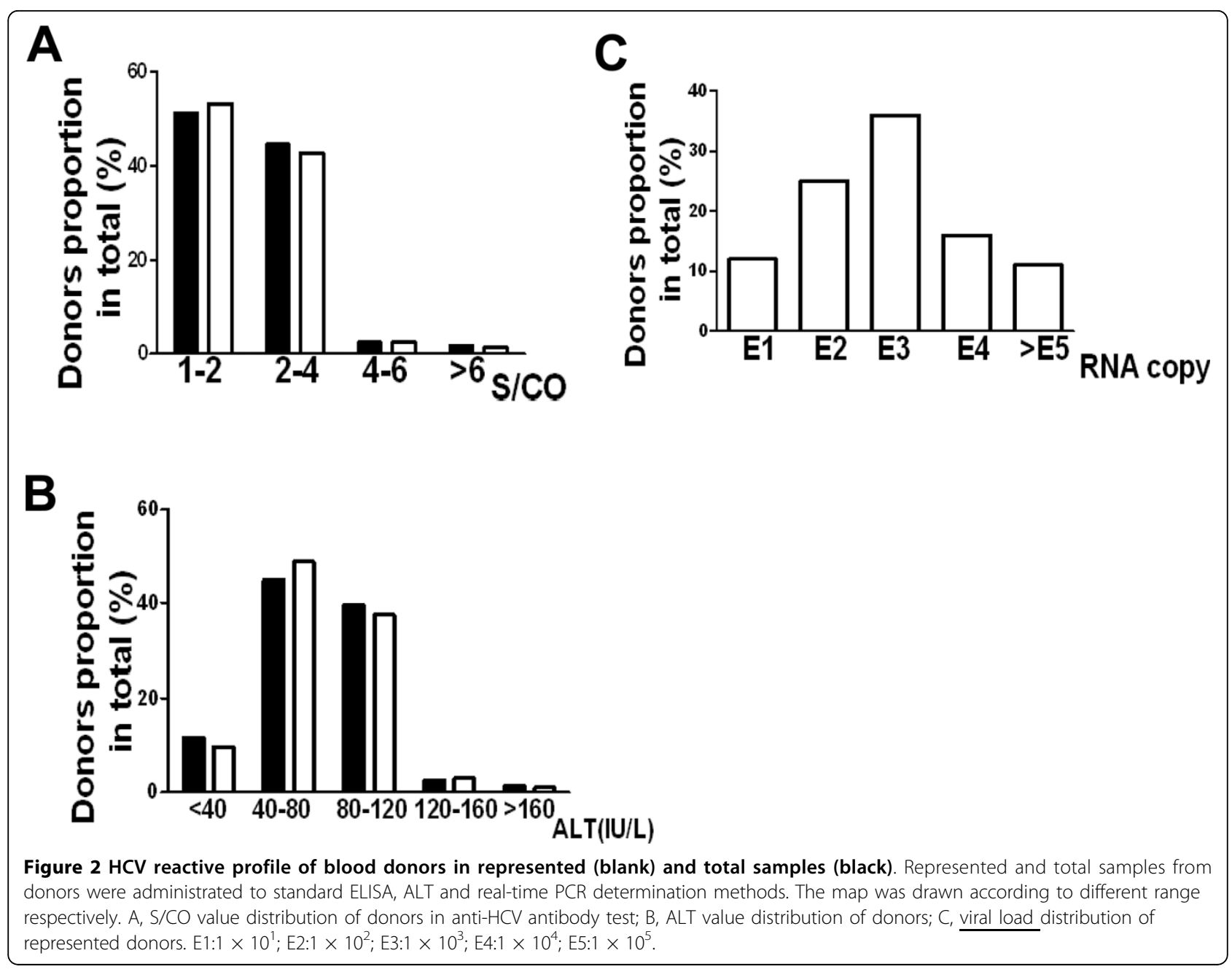

Table 1 Genotype distribution in anti-HCV reactive donors from 200 represented samples

\begin{tabular}{ccccc}
\hline Genotype & Cases & Percentage (\%) & Sex Ratio & Mean Age \\
\hline $1 \mathrm{a}$ & 10 & 5.0 & 2.1 & $41 \pm 10.1$ \\
1b & 135 & 67.5 & 1.1 & $39 \pm 11.6$ \\
$2 \mathrm{a}$ & 31 & 15.5 & 1.3 & $38 \pm 8.9$ \\
$2 \mathrm{~b}$ & 6 & 3.0 & 0.4 & $45 \pm 12.3$ \\
3a & 5 & 2.5 & 0.2 & $33 \pm 11.4$ \\
3b & 5 & 2.5 & 1.1 & $43 \pm 7.1$ \\
6a & 3 & 1.5 & 0.3 & $45 \pm 14.3$ \\
$1 \mathrm{~b}+2 \mathrm{a}$ & 2 & 1.0 & 0.8 & $34 \pm 11.3$ \\
NC & 3 & 1.5 & 0.7 & $29 \pm 8.7$ \\
\hline Total & 200 & 100 & $0.9^{*}$ & $36 \pm 9.7^{* *}$
\end{tabular}

Sex Ratio was counted on the Number of males to that of females. NC: Not clarified genotype.

*: Total sex ratio.

**:Total mean age. two main genotypes changed in the past years. As shown in Fig. 3, the cases of $1 \mathrm{~b}$ genotypes decreased in local HCV infected donors, from 16 cases in the year of 2000 to 11 cases in the year of 2009 (Fig. 3B), while the cases of 2a genotypes increased in the last 10 years(Fig. $3 \mathrm{C})$. Other genotypes did not change (data not shown). These results showed that in the past 10 years, the two main genotypes ( $1 \mathrm{~b}$ and $2 \mathrm{a}$ ) in local $\mathrm{HCV}$ infected donors underwent a switch, although not so markedly.

\section{ALT and viral load in follow up research}

To monitor HCV infection progress after the preliminary analysis, we tracked some reactive donors, who donated blood from the year of 2000 to the year of 2007 and were genotyped also as mentioned above, in the following 2 years. These samples were negative also for other hepatitis virus. Consecutive ALT testing showed that the liver function of these donors infected with $\mathrm{HCV}$, at least partly, impaired one year later or so after donation (Table 2). Especially, 1b genotype virus infected donors had a higher ALT level than that of 


\section{A}

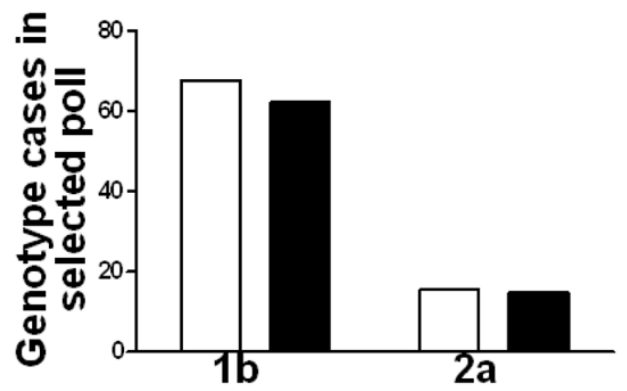

C

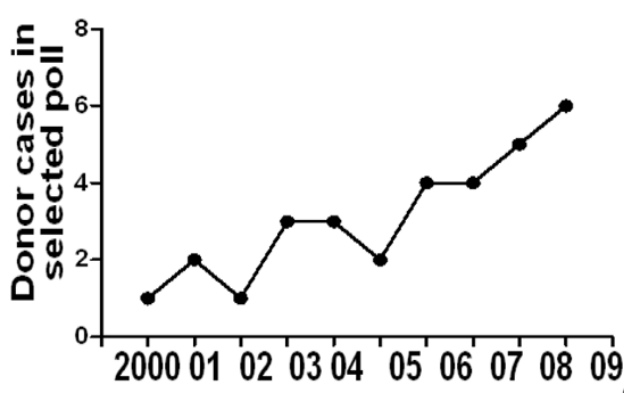

B

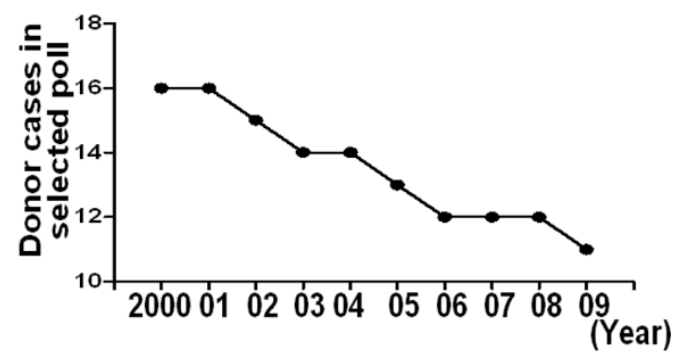

(Year)

Figure 3 Genotype distribution and switch in donors and patients. Blood sample form 200 represented donors and 100 patients were genotyped. Then genotype $1 \mathrm{~b}$ and $2 \mathrm{a}$ cases were counted. After that, rate of $1 \mathrm{~b}$ and $2 \mathrm{a}$ cases were distributed in different years. A, genotype $1 \mathrm{~b}$ and $2 \mathrm{a}$ comparison in donors (blank) and patients (black); B, genotype 1b distribution from the year of 2000 to 2009; C genotype 2a distribution from the year of 2000 to 2009.

other genotype virus infected donors in the follow up time (Table $2, P<0.05$ ). Virus load was serially quantitated by real-time PCR in the tracked donors. As shown in Table 3, the number of virus copies increased in all the donors. Once again, $1 \mathrm{~b}$ genotype virus RNA was higher in the follow up period $(P<0.05)$. Altogether, these data suggested that $1 \mathrm{~b}$ genotype infection led to more serious liver function impairment for local donors.

Table 2 ALT levels in the consecutive test of represented anti-HCV reactive donors

\begin{tabular}{|c|c|c|c|c|c|c|c|c|}
\hline \multirow[t]{2}{*}{ Donor Number } & \multirow[t]{2}{*}{ Genotype } & \multirow[t]{2}{*}{ Age } & \multirow[t]{2}{*}{ Sex } & \multicolumn{5}{|c|}{ ALT $\left(U . L^{-1}\right)$} \\
\hline & & & & 6 & 12 & 18 & 24 & (month) \\
\hline NO.17 & $3 a$ & 48 & $F$ & 30 & 41 & 48 & 57 & \\
\hline NO.26 & $1 b$ & 27 & $\mathrm{~F}$ & 48 & 66 & 80 & 118 & * \\
\hline NO.28 & $1 b$ & 41 & $M$ & 34 & 59 & 110 & 157 & * \\
\hline NO.43 & $2 a$ & 30 & F & 45 & 56 & $N D$ & 105 & \\
\hline NO.59 & $1 a$ & 41 & $M$ & 48 & 59 & 77 & 119 & \\
\hline NO.70 & $2 b$ & 50 & $M$ & 55 & 62 & 90 & 115 & \\
\hline NO.74 & $2 a$ & 35 & $M$ & 38 & ND & 71 & 93 & \\
\hline NO.77 & $1 b$ & 38 & $M$ & 54 & 79 & 93 & 147 & $*$ \\
\hline NO.93 & $\mathrm{NC}$ & 24 & F & 55 & 57 & 66 & ND & \\
\hline NO.96 & $1 b$ & 39 & $\mathrm{~F}$ & 44 & 49 & 73 & 127 & $*$ \\
\hline
\end{tabular}

ND: not determined. $*: P<0.05$ when compared to other genotypes.

\section{Discussion}

Since blood transfusion was generally accepted as one of the main dissemination pathways, more and more rigour test procedure was employed to detect $\mathrm{HCV}$ in donors [18]. In the current study, HCV average infection rate $(0.45 \%)$ in local donors was much lower than that of Chinese open population. One of the reasons might be the strict questionnaire before donation and a great

Table 3 HCV load in the following test of represented antibody reactive donors

\begin{tabular}{|c|c|c|c|c|c|c|c|c|}
\hline \multirow[b]{2}{*}{$\begin{array}{l}\text { Donor } \\
\text { Number }\end{array}$} & \multirow[b]{2}{*}{ Genotype } & \multirow[b]{2}{*}{ Age } & \multirow[b]{2}{*}{ Sex } & \multicolumn{5}{|c|}{ Viral load (copies/ml) } \\
\hline & & & & 6 & 12 & 18 & 24 & (month) \\
\hline NO.17 & $3 a$ & 48 & $\mathrm{~F}$ & $3.1 \mathrm{E} 1$ & $2.9 \mathrm{E} 2$ & $3.5 \mathrm{E} 2$ & $1.2 \mathrm{E} 3$ & \\
\hline NO.26 & $1 b$ & 27 & $\mathrm{~F}$ & $4.2 \mathrm{E} 2$ & $3.9 \mathrm{E} 2$ & $2.5 \mathrm{E} 3$ & $1.6 \mathrm{E} 4$ & * \\
\hline NO.28 & $1 b$ & 41 & $M$ & $4.5 \mathrm{E} 1$ & $4.9 \mathrm{E} 2$ & $6.5 \mathrm{E} 3$ & $2.5 \mathrm{E} 4$ & * \\
\hline NO.43 & $2 a$ & 30 & $F$ & 3.7E2 & $5.9 \mathrm{E} 2$ & ND & $1.5 \mathrm{E} 4$ & \\
\hline NO.59 & $1 a$ & 41 & $M$ & 4.4E2 & $3.8 \mathrm{E} 2$ & $3.5 \mathrm{E} 3$ & 1.9E4 & \\
\hline NO.70 & $2 b$ & 50 & $M$ & $5.2 \mathrm{E} 2$ & $5.9 \mathrm{E} 2$ & 8.0E3 & NC & \\
\hline NO.74 & $2 a$ & 35 & $M$ & $3.2 \mathrm{E} 1$ & ND & 4.0E3 & $7.4 \mathrm{E} 3$ & \\
\hline NO.77 & $1 b$ & 38 & $M$ & $3.2 \mathrm{E} 2$ & $4.9 \mathrm{E} 3$ & $9.0 \mathrm{E} 3$ & $2.4 \mathrm{E} 4$ & * \\
\hline NO.93 & NC & 24 & $\mathrm{~F}$ & $3.1 \mathrm{E} 1$ & 2.9E2 & $3.5 \mathrm{E} 2$ & ND & \\
\hline N0.96 & $1 b$ & 39 & $\mathrm{~F}$ & $2.2 \mathrm{E} 2$ & 3.9E2 & $6.5 \mathrm{E} 3$ & $1.8 \mathrm{E} 4$ & * \\
\hline
\end{tabular}

ND: not determined. ${ }^{*}: P<0.05$ when compared to other genotypes. 
number of carriers were ruled out. On the other hand, the questionnaire could not deny the possibility of lowgrade infection, thus the value of $\mathrm{S} / \mathrm{CO}$ and virus RNA in most anti-HCV reactive donors in the present study were not so high.

The infection rate decreased from the year of 2004, in which gold-fast strip test was used before blood collection in our blood bank. Actually, without gold-fast strip test, the infection rate was much close to Sosa-Jurado et al reports $(0.81 \%$ v.s. $0.84 \%)$. Interestingly, they observed descending $\mathrm{HCV}$ infection rate also from the year of 2003 to 2006 and contributed this decrease to stringent questionnaire [11].

Genotyping of $\mathrm{HCV}$ is necessary for clinic treatment and care counseling $[19,20]$. It is also useful to monitor the virus strains distribution profile and identify risk factors involved with transmission [11,21]. Blood transfusion was one of the main dissemination pathways. Thus it is great significant to analyze $\mathrm{HCV}$ genotype distribution for the sake of infection control. Although bulks of data described $\mathrm{HCV}$ genotype distribution in donors from different region $[7,8,11,16]$, the situation in different region of China is somewhat unknown. Thus according to our knowledge, the present study firstly displayed the $\mathrm{HCV}$ genotype distribution in local region.

Althougth NS5b region sequences is thought as the most reliable technique for subtyping, hitherto 5 ' non coding region of $\mathrm{HCV}$ was the one of the most conserved sequence and thus extensively adapted in subtype discrimination, especially in clinic $\mathrm{HCV}$ investigation. Other HCV gene fragments can also be used for genotyping. But they are not so popular because of more possible mutation, uncertain PCR products, less convenience and much higher costs in clinic. Before better and mature genotyping strategy innovation, 5 ' non coding region of $\mathrm{HCV}$ is the feasible choice for clinic investigation.

As occurred in other Eastern Asia region, $1 \mathrm{~b}$ and 2a subtype prevailed in local region although other subtypes were observed also $[16,17,22]$. What's more, we found that the main prevailed subtypes in patients and donors were no difference. Interestingly, $1 \mathrm{~b}$ and $2 \mathrm{a}$ subtype in local HCV infected donors underwent a switch. Donors infected with $1 \mathrm{~b}$ virus descended in the past years, while donors infected with $1 \mathrm{~b}$ virus climbed. It is not clear yet why this switch happened. One of the possible machinery is the population mobility. In fact $1 \mathrm{~b}$ virus infection was prevailed in the south region of China and 2a virus infection was prevailed in the north region of China [23]. Since local city is at the cross of south and north, the observed subtype switch was no strange.

To track the donor's HCV infection, we made a twoyears follow up in some anti-HCV reactive donors.
Bulks of evidence showed that $1 \mathrm{~b}$ genotype could bring more serious damage to liver [24]. Since we have ruled out other hepatitis virus infection, our data was consistent with that postulation according to the ALT level in the followed time. Again, viral load measurement also confirmed that $1 \mathrm{~b} \mathrm{HCV}$ virus duplicated more quickly than other genotypes did, which contributed to the liver function damage [25].

\section{Conclusion}

The current study provided data of HCV infection in China blood donors during the past ten years. The infection rate in local donors was lower than general population and descended in recent years. Genotypes were clarified in the represented donor sample pool and $1 \mathrm{~b}$ subtype was the prevailed strains. But $1 \mathrm{~b}$ and $2 \mathrm{a}$ genotype switched in the past years in local region. These results threw more light on $\mathrm{HCV}$ infection of blood donors in China, at least in the Northern region.

\section{Materials and methods}

\section{Blood donor, sample collection and follow up}

Volunteer blood donors from both urban and rural areas in Xi'an City, from January of 2000 to December of 2009, were recruited into current study. They were medically assessed and denied any known risk factors for viral infection listed in the questionnaire. 200 donors with HCV (20 donors each year), ruled out HBV infection, were asked to give peripheral blood samples for genotyping. The serum were isolated from the samples, then subpackaged and stored at $-80^{\circ} \mathrm{C}$ before analysis. Ten samples from the chosen 200 donors (donated before the December of 2007 and negative for other hepatitis virus) were followed up in the next 2 years. The sampling, isolation and storage procedures were just like the mentioned above. The present study was approved by the Ethics Committee of Fourth Military Medical University and the informed consents were signed.

\section{ELISA for anti-HCV detection}

Test of the anti-HCV antibody were performed by ELISA using automatic enzyme detection system (Tecan GroupLtd., Mannedorf, Switzerland) and commercial kit (InTec Products, Xiamen, China). Briefly, 96-well plates were coated with antigen. Donors' peripheral blood serum was isolated and added into wells by automatic enzyme detection system before incubation. The plates were subsequently washed 5 times with PBST, and then the horseradish peroxidase labeled mono-antibody was added. After incubation, followed the manufacturer's instructions, washed plates and developed colorant to determine the results with absorbance reader (Thermo Scientific, Wohlen, Switzerland). 


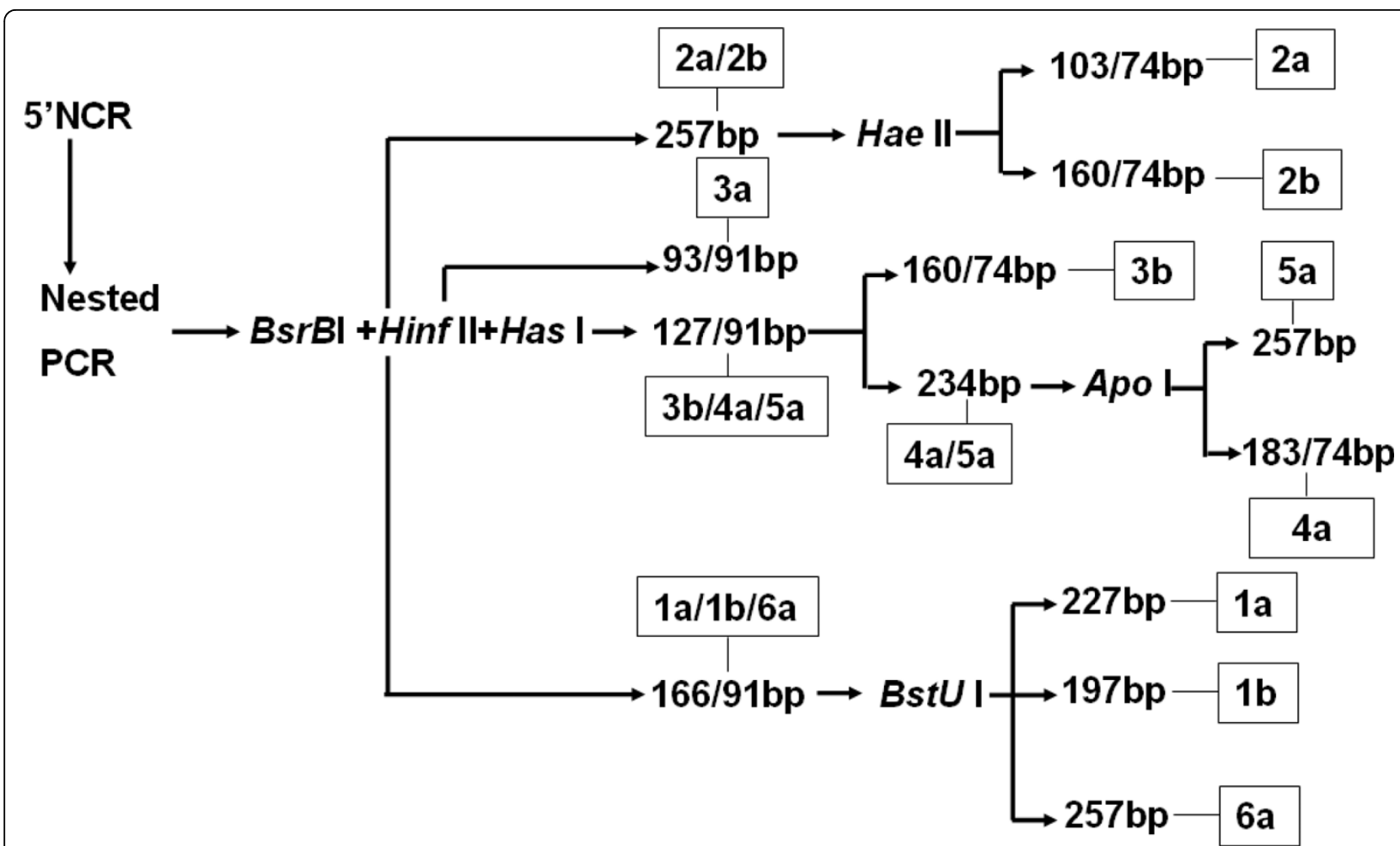

Figure 4 The scheme of genotyping of HCV from recruited volunteer donors. Samples were prepared and nested-PCR was performed. After that, serial restriction enzyme digestion was administrated to PCR products according to reports[7,8,20].

\section{Alanine-aminotransferase (ALT) measurement}

To measure the ALT level, donors' peripheral blood serum was isolated and employed to automatic biochemistry analyzer (Hitachi, Tokyo, Japan) with commercial Kit (Fousun Long March Medical Ltd., Shanghai, China).

\section{Nucleic acid assay of HCV viral load}

RNA from donor's blood sample was prepared according to the manufacturers' manual (Qiagen, Hilden, Germany). In brief, $500 \mu \mathrm{l}$ isolated serum was mixed with $500 \mu \mathrm{l}$ TRIzol regent and extracted with chloroform and alcohol. After quantitation, reverse transcribed into cDNA using random primers was performed (Qiagen, Hilden Germany). After that, real time PCR was used to detect HCV RNA according the manufacture's manual (Daan Gene, Shenzhen, China) with standard controls $[3,26]$. Briefly, extracted RNA was measured with fluorescence labeled and self-quench probe and Perkin Elme PCR analyzer (PTC-200, Perkin Elmer, Covina, USA). The viral load used the copies/ml as the units.

\section{Genotyping}

Genotyping was accomplished according to reported methods [7,8,27]. Briefly, Extracted RNA from the peripheral blood of 200 donors or 100 confirmed patients. Then the reverse transcription with random hexaprimers was carried out. After that, the seminested PCR of the 5' non-coding region with generic primers were performed. Amplicons were digested by restriction enzymes (Takara, Osaka, Japan). The digestion model, possible products and genotype categorization were schemed in Fig. 4.

\section{Statistical analysis}

Differences between groups were statistically analyzed using SPSS 10.0. When $P<0.05$, the difference was considered significant.

\section{Acknowledgements}

We are thankful for the support of the Blood Bank of Xi'an, PLA.

\section{Author details}

${ }^{1}$ Department of Clinic Molecular Research Center\& Clinic Diagnostic Laboratory, Xijing Hospital, Fourth Military Medical University, 17th Changlexi Road, Xi'an 710032, China. 'Department of Blood Transfusion, Xijing Hospital, the Fourth Military Medical University,17th Changlexi Road, Xi'an 710032, China. ${ }^{3}$ School of Electronic Information Engineering, Xi'an Technological University, xi'an 710032, China.

\section{Authors' contributions}

YQH carried out the donor screen and drafted the manuscript. ZXQ participated in the real time PCR. SY performed statistics analysis. CYZ performed ALT analysis. SWL and SMQ carried out follow-up. MSJ, HXKand 
HXB predicated in the design of the study. All authors read and approved the final manuscript.

\section{Competing interests}

The authors declare that they have no competing interests.

Received: 1 June 2010 Accepted: 10 August 2010

Published: 10 August 2010

\section{References}

1. Lavanchy D: The global burden of hepatitis C. Liver Int 2009, 29(Suppl 1):74-81.

2. Ray Kim W: Global epidemiology and burden of hepatitis C. Microbes Infect 2002, 4(12):1219-1225.

3. Hu XB, Yue QH, Ouyang HF, Chen $Y Z$, Xu XQ, Yin W, Wei SH, Zhang XQ $\mathrm{Mu} \mathrm{SJ:} \mathrm{Immune} \mathrm{response} \mathrm{to} \mathrm{fused} \mathrm{core} \mathrm{protein} \mathrm{of} \mathrm{hepatitis} C$ virus and truncated tetanus toxin peptides in mice. Arch Virol 2010, 155(7):1097-1105.

4. Chevaliez S, Pawlotsky JM: Hepatitis C virus serologic and virologic tests and clinical diagnosis of HCV-related liver disease. Int J Med Sci 2006, 3:35-40.

5. Choo QL, Richman KH, Han JH, Berger K, Lee C, Dong C, Gallegos C, Coit D Medina-Selby R, Barr PJ, et al: Genetic organization and diversity of the hepatitis C virus. Proc Natl Acad Sci USA 1991, 88:2451-2455.

6. Stuyver L, van Arnhem W, Wyseur A, Hernandez F, Delaporte E, Maertens G: Classification of hepatitis $C$ viruses based on phylogenetic analysis of the envelope 1 and nonstructural $5 B$ regions and identification of five additional subtypes. Proc Natl Acad Sci USA 1994, 91:10134-10138.

7. Cantaloube JF, Gallian P, Attoui H, Biagini P, De Micco P, de Lamballerie X Genotype distribution and molecular epidemiology of hepatitis $C$ virus in blood donors from southeast France. J Clin Microbiol 2005, 43:3624-3629.

8. Cantaloube JF, Laperche S, Gallian P, Bouchardeau F, de Lamballerie X, de Micco P: Analysis of the $5^{\prime}$ noncoding region versus the NS5b region in genotyping hepatitis $\mathrm{C}$ virus isolates from blood donors in France. J Clin Microbiol 2006, 44:2051-2056.

9. Robertson B, Myers G, Howard C, Brettin T, Bukh J, Gaschen B, Gojobori T, Maertens G, Mizokami M, Nainan O, et al: Classification, nomenclature, and database development for hepatitis $\mathrm{C}$ virus $(\mathrm{HCV})$ and related viruses: proposals for standardization. International Committee on Virus Taxonomy. Arch Virol 1998, 143:2493-2503.

10. Hino K, Yamaguchi $Y$, Fujiwara D, Katoh $Y$, Korenaga M, Okazaki M, Okuda M, Okita K: Hepatitis $C$ virus quasispecies and response to interferon therapy in patients with chronic hepatitis C: a prospective study. J Viral Hepat 2000, 7:36-42.

11. Sosa-Jurado F, Santos-Lopez G, Guzman-Flores B, Ruiz-Conde Jl, MelendezMena D, Vargas-Maldonado MT, Martinez-Laguna Y, Contreras-Mioni L, Vallejo-Ruiz V, Reyes-Leyva J: Hepatitis C virus infection in blood donors from the state of Puebla, Mexico. Virol J 7:18.

12. Castera L, Hezode C, Roudot-Thoraval F, Lonjon I, Zafrani ES, Pawlotsky JM, Dhumeaux D: Effect of antiviral treatment on evolution of liver steatosis in patients with chronic hepatitis C: indirect evidence of a role of hepatitis C virus genotype 3 in steatosis. Gut 2004, 53:420-424.

13. Kumar D, Farrell GC, Fung C, George J: Hepatitis C virus genotype 3 is cytopathic to hepatocytes: Reversal of hepatic steatosis after sustained therapeutic response. Hepatology 2002, 36:1266-1272.

14. Seeff LB, Hoofnagle JH: Appendix: The National Institutes of Health Consensus Development Conference Management of Hepatitis C 2002. Clin Liver Dis 2003, 7:261-287.

15. Arase $Y$, Ikeda $K$, Tsubota A, Suzuki $Y$, Saitoh S, Kobayashi M, Akuta N, Someya T, Suzuki F, Kumada $\mathrm{H}$ : Randomized trial of prolonged interferon retreatment for chronic hepatitis $C$ patients with HCV-genotype $1 \mathrm{~b}$ and high virus load. Hepatol Res 2003, 25:364-370.

16. Fu Y, Wang Y, Xia W, Pybus OG, Qin W, Lu L, Nelson K: New trends of HCV infection in China revealed by genetic analysis of viral sequences determined from first-time volunteer blood donors. J Viral Hepat 2010.

17. Fu Y, Xia W, Wang Y, Tian L, Pybus OG, Lu L, Nelson K: The seroprevalence of hepatitis $C$ virus (HCV) among 559,890 first-time volunteer blood donors in China reflects regional heterogeneity in HCV prevalence and changes in blood donor recruitment models. Transfusion 2010, 50:1505-1511.
18. Zhao SM, Jiang TL, Gao FX, Lu L, Zheng HQ, Hu J, Fan YH, Li B, Xiao RR, Yury K: Analysis of true voluntary blood donors with anti-HCV prevalence and implications for donor management in Chongqing, China. Transfus Med 2007, 17:210-211.

19. Simmonds P: Genetic diversity and evolution of hepatitis $C$ virus-15 years on. J Gen Virol 2004, 85:3173-3188.

20. Simmonds P, Bukh J, Combet C, Deleage G, Enomoto N, Feinstone S, Halfon P, Inchauspe G, Kuiken C, Maertens G, et al: Consensus proposals for a unified system of nomenclature of hepatitis $C$ virus genotypes. Hepatology 2005, 42:962-973.

21. Santos-Lopez G, Sosa-Jurado F, Vallejo-Ruiz V, Melendez-Mena D, Reyes Leyva J: Prevalence of hepatitis $C$ virus in the Mexican population: a systematic review. J Infect 2008, 56:281-290.

22. Lu L, Nakano T, He Y, Fu Y, Hagedorn CH, Robertson BH: Hepatitis C virus genotype distribution in China: predominance of closely related subtype $1 \mathrm{~b}$ isolates and existence of new genotype 6 variants. J Med Virol 2005, 75:538-549.

23. Qiu GH, Du SC, Sun NX, You P, Fan XF, Zhang YX, Wei L: [Hepatitis c virus genotype research by $A B C$ programs of 5 -NCR restriction endonuclease digestion]. Zhonghua Gan Zang Bing Za Zhi 2004, 12:237-239.

24. Wiley TE, Brown J, Chan J: Hepatitis C infection in African Americans: its natural history and histological progression. Am J Gastroenterol 2002, 97:700-706.

25. Blatt LM, Mutchnick MG, Tong MJ, Klion FM, Lebovics E, Freilich B, Bach N, Smith $\mathrm{C}$, Herrera J, Tobias $\mathrm{H}$, et al: Assessment of hepatitis $\mathrm{C}$ virus RNA and genotype from 6807 patients with chronic hepatitis $C$ in the United States. J Viral Hepat 2000, 7:196-202.

26. Hu XB, Yue $Q H$, Zhang $X Q$, Xu XQ, Wen $Y$, Chen $Y Z$, Cheng XD, Yang $L$, Mu SJ: Hepatitis B virus genotypes and evolutionary profiles from blood donors from the northwest region of China. Virol J 2009, 6:199.

27. Liu LJ, Zhang R, Li JQ, Du SC, Jin D, Wei L: [The distribution of hepatitis C virus genotype 1a in Yanbian area]. Zhonghua Yi Xue Za Zhi 2007 87:1407-1410.

doi:10.1186/1743-422X-7-186

Cite this article as: Yue et al:: Anti-HCV reactive volunteer blood donors distribution character and genotypes switch in Xi'an, China. Virology Journal 2010 7:186

\section{Submit your next manuscript to BioMed Central and take full advantage of:}

- Convenient online submission

- Thorough peer review

- No space constraints or color figure charges

- Immediate publication on acceptance

- Inclusion in PubMed, CAS, Scopus and Google Scholar

- Research which is freely available for redistribution
Biomed Central 